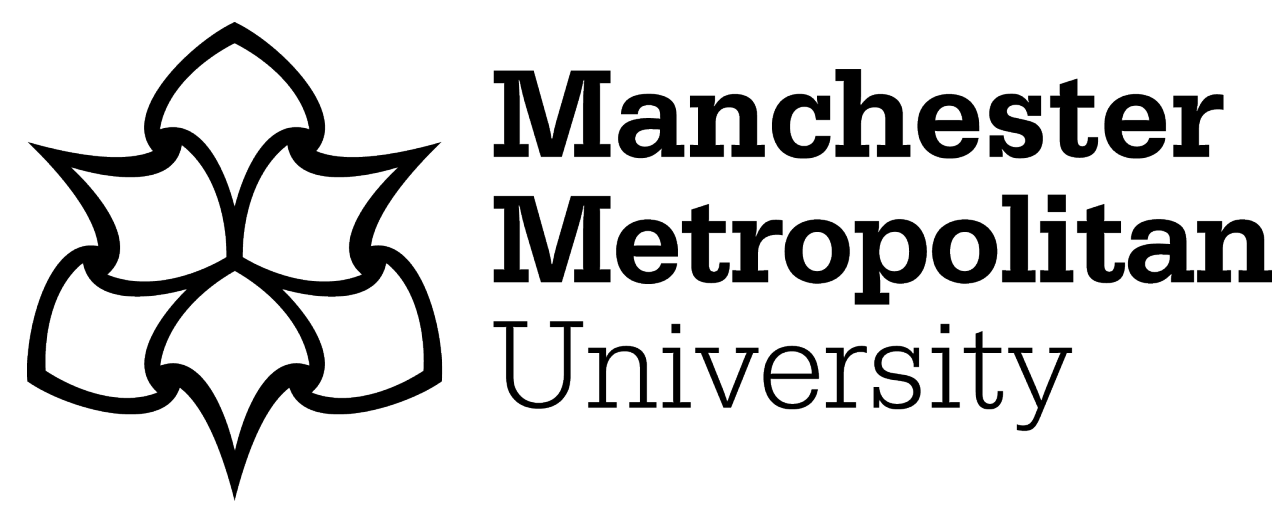

McLaughlin, KP (2018) Public and Private Social Realities in the Poesía de Circunstancias of Catalina Clara Ramírez de Guzmán. Modern Language Review, 113 (4). pp. 753-777. ISSN 0026-7937

Downloaded from: https://e-space.mmu.ac.uk/620384/

Publisher: Modern Humanities Research Association

DOI: https://doi.org/10.5699/modelangrevi.113.4.0753

Please cite the published version 


\title{
PUBLIC AND PRIVATE SOCIAL REALITIES IN THE POESÍA DE CIRCUNSTANCIAS OF CATALINA CLARA RAMÍREZ DE GUZMÁN
}

\begin{abstract}
This article examines the occasional verse of the little-known Spanish writer Catalina Clara Ramírez de Guzmán (1618-c.1684). Straddling the public and private spheres, the large group of poems marking occasions ranging from official festivities and encomiastic celebrations of aristocrats to occurrences much closer to home constitute interesting examples of the social and familial use of verse in the seventeenth century. Partly literary and partly referential, they tell us a considerable amount about the author herself and, unlike much verse of this type, provide a clear connection with the real, everyday world.
\end{abstract}

Virtually every poet of the seventeenth century penned occasional verse. Originating with the classical Latin poets, occasional poetry, including odes to monarchs and other public figures on events of importance such as birthdays, weddings and funerals, has always been a more or less formal component of public and even political poetry. ${ }^{1}$ However, despite occupying in many cases a significant place among an author's writings, the verses falling within this category are often relegated to a marginal position in terms of critical attention, a contradiction underlined by Hegel, among others:

The art of poetry should not seek to maintain an absolutely isolated position in the real world, but must, as itself living, enter into the midst of life. Poetry's living connection with the real world and its occurrences in public and private affairs is revealed most amply in the so-called pièces d'occasion [...] But by such entanglement with life poetry again seems to fall into a position of dependence, and for this reason it has often been

\footnotetext{
${ }^{1}$ It will be recalled that in England the creation of the position of Poet Laureate in 1668 aimed specifically to institutionalise the genre in the service of the recently restored Stuart monarchy, particularly through odes to the King.
} 
proposed to assign to the whole sphere of pièces d'occasion an inferior value although, to some extent, especially in lyric poetry, the most famous works belong to this class. ${ }^{2}$

This same contradiction might be said to exist also in the case of the poems of Catalina Clara Ramírez de Guzmán (1618-c.1684), which can be included under the heading of occasional verse or 'poesía de circunstancias', ${ }^{3}$ a category that accounts for a substantial proportion of the production of this relatively little-known and understudied author. Ramírez de Guzmán, born into an affluent and influential family in the Extremaduran town of Llerena, ${ }^{4}$ neither married nor entered a convent and, as far as is known, virtually nothing of her work was published in her lifetime. However, a surviving corpus of approximately 120 poems contained in two manuscripts in Madrid's Biblioteca Nacional (Mss. 3884 and 3917), together with various references to a lost novella entitled El Extremeño and an unnamed comedia, indicate that she was a prolific and versatile writer. ${ }^{5}$ Among Hispanic women poets of the early modern period, only Sor Juana Inés de la Cruz comes close to matching the Extremaduran in terms of the production of occasional poetry. As this article will attempt to demonstrate, the large group of approximately 50 poems (almost half of her extant production) that record or commemorate specific occasions, events and individuals occupies a prominent place in

\footnotetext{
${ }^{2}$ Georg Hegel, Aesthetics. Lectures on Fine Art. Translated by T.M. Knox. Vol. 2. (Oxford: Clarendon Press, 1998), pp. 995-96.

${ }^{3}$ According to Inmaculada Osuna, the category comprises 'un conjunto de versos relativamente vario, pese a contar con el denominador común de la asunción de motivos poéticos del ámbito espacio-temporal en que se desenvuelven sus autores; naturalmente, esa relación con el entorno será susceptible de diversas particularizaciones, y, así, podremos encontrar poemas que remiten a acontecimientos históricamente constatables $[\ldots]$ y poemas que, por el contrario, escogen motivos laudatorios más genéricos, sin una motivación cronológica precisa'. See Inmaculada Osuna, Poesía y Academia en Granada en torno a 1600: La poética silva (Sevilla: Secretariado de Publicaciones de la Universidad de Sevilla, 2003), p. 164. ${ }^{4}$ The growing importance of the town as of the mid-sixteenth century led Philip IV to grant it city status in 1640 .

${ }^{5}$ For a modern edition of her poetry and full biographical details, see Catalina Clara Ramírez de Guzmán, Obra Poética, ed. with Introduction and Notes by Aránzazu Borrachero Mendíbil and Karl McLaughlin (Mérida: Editora Regional de Extremadura, 2010). All quotes from the poems of Ramírez de Guzmán will be taken from this edition. For ease of reference, poem numbers (for example, CXII) will be given instead of full titles, unless the latter are specifically required.
} 
Ramírez de Guzmán's writings. Straddling the public and private spheres, the poems constitute interesting examples of the social and familial use of verse in the seventeenth century and enter fully into 'the midst of life' referred to by Hegel. Similar in some respects to the popular comedias of the Golden Age in terms of the costumbrista snippets of day to day life which they offer, in many cases the poems represent an interesting historiographic contribution to our knowledge of a lesser-known Castilian city from the second third of the century onwards. These partly literary and partly referential texts also tell us a considerable amount about the author herself, particularly her relationships within both her domestic and broader social contexts.

Although inevitably conditioned by the conventions of poetic representation followed by the writers of the Baroque, the poemas de circunstancias by Ramírez de Guzmán illuminate for modern-day readers valuable aspects of the social reality of provincial Spain during the period and therefore deserve our attention for their undoubted socio-historical value. Time and space do not permit an analysis of all the pieces but a discussion of a representative sample will help draw out the social connections underpinning the poems and will also serve to demonstrate that an 'occasion' for Ramírez de Guzmán did not necessarily have to be of the kind typically reflected in the genre. While a number do fall within the category of verses directed to public figures or events, many deal with more private occasions relating to the poet's family and, beyond this, to her immediate social environment in Llerena. Both these aspects - public and private - will be addressed in the discussion which follows. 


\section{Public occasion poetry}

In keeping with the contemporary literary fashion of eulogies of influential aristocrats, ${ }^{6}$ the poetry of Ramírez de Guzmán includes a long ballad addressed to one of the most important military figures of the middle of the seventeenth century, the Duke of San Germán, Commander of the Spanish forces in Extremadura during the war with Portugal. The poem is particularly noteworthy since it is the only instance of a culteranista panegyric among her surviving writings and marks a clear departure from her characteristic style. The praise of the Duke in this stylised and formulaic litany of virtues and achievements conforms closely to the prescribed rhetorical canons of laus, including the obligatory references to the importance of his lineage, the hyperbole-filled allusions to his bravery and other attributes, his deserved eternal glory, etc. ${ }^{7}$ In verses recalling the heroic eulogies by court poets, she extols in quasi-epic style the military feats of the Duke:

Del glorioso San Germán,

milagros cante la fama

y, coronista, su pluma,

eternice sus hazañas

$[\ldots]$

Triunfó de su bizarría

la rebelde Lusitania,

\footnotetext{
${ }^{6}$ The popularity of such eulogies during the period is explained, in large measure, by the ever-growing role of aristocratic patrons in the Arts in general. The nobility of the seventeenth century took an active role in artistic promotion, often as a means of self-elevation. As the literature of the day shows clearly, patronage was acknowledged through laudatory poetry to sponsors.

${ }^{7}$ According to González Maya, the canons included 'la repetición de unas fórmulas, convertidas en algunos casos en tópicos. La estructura del elogio abarca los siguientes modi tractandi, no siempre aislados ya que a veces se dan la mano con otros recursos como la súplica: la grandeza de la Casa nobiliaria; la etopeya del retratado como espejo donde mirarse; los atributos más variados (generosidad, belleza, espíritu guerrero, honradez, nobleza, galanura, valentía...); los deseos de fertilidad y de vida eterna, los buenos augurios en cualquiera de las facetas de sus vidas; la estimación popular y respeto; los milagros de que son capaces.' See Jerónimo de Cáncer y Velasco, Poesía completa, ed. by Juan Carlos González Maya (Madrid: Fundación Universitaria Española, 2007), p. 63.
} 
sino la obliga el agrado,

la conquistara por armas. (CXII, 1-4, 53-56)

The multiple references to military victories in 'las plazas enemigas' such as Olivenza, Alconchel and Castillo de Morón (29-45) evidence the author's detailed knowledge of the latest developments in the long-running conflict on the region's borders. The victories and other achievements were, in her opinion, more than sufficient for Philip IV to elevate San Germán to grandee status:

Goce de su Rey mercedes

cuantas le presenta hazañas, que el blasón de merecerlas

acompaña el de lograrlas.

De Capitán General

el bastón que trae por gala

sea báculo a que se arrimen

las grandezas que le aguardan.

Ser Grande, sea la menor

merced con que satisfaga

el cuarto Felipe, el Grande;

finezas son bien logradas.

¡Vivas mas años que el tiempo!

Y sus heroicas hazañas,

sin conocer el olvido,

mejores fénix renazcan. (CXII, 57-72) ${ }^{8}$

\footnotetext{
${ }^{8}$ In another poem in praise of a local aristocrat, Ramírez de Guzmán expresses the hope that the Marquis of Estepa will be made a grandee also: 'Si es marqués por excelencia, | Duque por merced será | y justicia
} 
However, although sharing many features of the numerous eulogies of nobles found in the works of poets of the era, the ballad differs in one crucial respect: the lavish praise heaped on the Duke for his heroics turns out to be merely an introductory pretext allowing Ramírez de Guzmán to move on to the true subject of the poem: the Duke's wife.

Despite the ballad's title ('Romance al Duque de San Germán'), Catalina de Cárdenas ('Cloris') occupies the remaining two thirds of the poem and is addressed directly throughout. The highly personal tone of the piece is emphasised through the repeated use of 'tú' at the beginning of eight central strophes, which contain specific allusions to the family background and Madrid origins of the Duchess and extol her beauty and virtues using the stock hyperbole:

Y tú, bellísima Cloris,

cuya beldad extremada

trasladó, de Manzanares,

milagros a Guadiana;

tú, la más hermosa Venus,

que, a mirarte Juno y Palas,

celebrando el vencimiento

te ofrecieran la manzana;

$[\ldots]$

tú, que eres compuesto bello

en quien lo mejor se halla,

imán de las voluntades

se le hará $\mid$ a tan hidalga ascendencia $\mid$ digna de la preeminencia $\mid$ de que el Rey cubrir le mande $\mid$ y de que liberal ande | en darle honores y oficios, | que a su sangre y sus servicios | le viene chico el ser grande' (XXXIII, 11-20). 
$\mathrm{y}$ atractivo de las almas,

dulcísimo laberinto,

en quien se pierde y se halla

la más libre voluntad

en su cautiverio, vana. (CXII, 73-80, 111-118)

As mentioned above, this extremely formal ballad is unique among the poems of Ramírez de Guzmán on account of its elevated style, which is totally devoid of the hallmark conceptista plays seen in other pieces, and its overtly personal tone in conveying the author's devotion to her noble friend and desire to serve her. The romance, in which the rhetorical ploy of modesty (captatio benevolentiae) regularly found in such pieces is adopted (elevating the virtues of the Duchess while understating her own talents), ${ }^{9}$ can be viewed as fulfilling an important strategic function for Ramírez de Guzmán as a vehicle for social advancement by cultivating the friendship of one of the most influential noble families of the period: ${ }^{10}$

\footnotetext{
${ }^{9}$ Ana Caro adopts a similar strategy in opening her poetic account of the festivities staged by Franciscan friars in Seville in honour of the Holy Martyrs of Japan (1628): 'Recebid, señor Juan de Elossidieta, | este rudo discurso en vuestro amparo | que de mano tan tosca e imperfecta | sale a luzir a vuestro valor raro'. See Manuel Serrano y Sanz, Apuntes para una biblioteca de escritoras españolas desde el año 1401 al de 1803, 2 vols. (Madrid: Rivadeneyra, 1903-05), I, p. 214. Various critics have drawn attention to the use of the rhetoric of humility and other strategies by women writers to circumvent the strict gender codes that were intended to rob them of access to intellectualism. See, for example, Lisa Vollendorf, " Llevar una opinión contraria": The Evolution of Early Modern and Colonial Women's Studies', Letras Femeninas 35.1 (2009), 25-41 (p. 27). According to Mújica, Early Modern women authors tended to exceed the formal requirements of this rhetorical admission of inadequacy, perhaps due to doubts as to their literary abilities. See Bárbara Mújica, Women Writers of Early Modern Spain. Sophia's Daughters (New Haven: Yale University Press, 2004), p. xlvi.

${ }^{10}$ As Daems notes 'occasional verse was also written to negotiate a poet's social status, particularly in relation to patronage'. See James Daems, Seventeenth-Century Literature and Culture (London: Continuum, 2006). p. 54. Another poem, on the absence of the Count and Countess of La Puebla, can also be viewed in this context. The poem opens thus: 'De los Condes el ausencia | siente el lugar a porfía, | pues consiste su alegría $\mid$ en que dure su asistencia' (XCIX, 1-4). Fox mistakenly believed this to be the only poem written by the author to nobles: "Ramírez writes no sycophantic poetry to other notables, with the single exception of a décima 'a la ausencia de los Condes de la Puebla'". See Gwyn Fox. 'Hearts in the Hearth: Seventeenth-Century Women's Sonnets of Love and Friendship in Spain and Portugal', (unpublished doctoral thesis, University of Auckland, 2004), p. 43. An interesting contrast to these poems of praise is CII, also addressed to a noble ('A el Marqués del Dragón de San Miguel') but on this occasion to rebuke him for damage he caused to the Ramírez family chapel.
} 
Admite, oh ilustre Duquesa,

a mi humildad siempre grata

amorosos desaliños

que mi Euterpe te consagra.

Travesuras de mi pluma

bien sentida y mal cortada:

a tu peregrino ingenio

dedica mis inorancias.

Recibe en roncos acentos

que mi ruda avena canta,

una inclinación, Señora,

y una voluntad esclava. (CXII, 167-78)

Although Ramírez de Guzmán, who was almost 40 years of age when she wrote the poem - the references to military successes of 1657 allow us to fix an approximate date of composition -, was sufficiently well-off not to have to depend on patronage for her livelihood (unlike many male poets of the day) and had little need of official endorsement for her literary creations, the romance dedicated to San Germán and his wife suggests some desire to enjoy, if not protection (the poet expresses the hope in the closing lines that the Duke's family will be her 'guardian angels' and 'Seraphim'), at least the valuable social status attached to privileged ties with the influential aristocrats. $^{11}$

${ }^{11}$ The social importance of relations between writers and aristocrats or members of circles of power during the period is examined by, among others, Gutiérrez, who analyses the differences between clientelism and patronage and the types of literary creation associated with each. See Carlos M. Gutiérrez, 'The Challenges of Freedom: Social Reflexivity in the Seventeenth-Century Spanish Literary Field', in Hispanic Baroques: Reading Cultures in Context, ed. by Nicholas Spadaccini and Luis Martín-Estudillo (Nashville: Vanderbilt University Press, 2005), pp. 137-61. The poem by Ramírez de Guzmán is evidence 
The ballad is not the only poem written by Ramírez de Guzmán to public figures in positions of influence. An easily-overlooked décima offers interesting historical insight into the politics of Llerena (XXX). ${ }^{12}$ The flirtatious recommendation to a senior Inquisition official to leave behind his tiresome junior - the 'secretario muy necio' of the title - when making social calls to ladies (presumably Ramírez de Guzmán and her sisters or friends) is conveyed succinctly in the author's typical style, including her characteristic closing wordplay:

Muy bien pueden apostar, si se permite decir, el fiscal a divertir, y el secretario a cansar.

Por consejo le he de dar al visitador fiel, para no hacer el crüel trabajo tan ordinario, que escriba con secretario y que visite sin él. (XXX, 1-10)

This rare literary mention of the social side of Inquisition work is valuable in helping further complete our picture of Llerena social life, not to say the Ramirez de Guzmán family's networking. The official is clearly on friendly terms with the poet (otherwise she would not have dared to pen the rebuke), and may well have participated in

that the same dynamics of patronage generated by the massive social, cultural, economic and political movement towards Madrid in the seventeenth century, with the inevitable impact on artists and writers, operated in the peripheral provinces also.

12 'A un fiscal de corte que, siendo visitador de la Inquisición, visitó a unas señoras en compañía de un Secretario muy necio que le asistía siempre'. It is worth noting that Llerena was home to one of the country's largest Inquisition Tribunals in terms of jurisdiction, covering more than $42,000 \mathrm{~km}^{2}$. Established in 1508, the Tribunal had three permanent seats in the city. 
entertainment organised at the family home. Indeed, Ramírez de Guzmán could even be said to be exhibiting a considerable degree of self-confidence in using her verses to voice criticism of the secretary without, one assumes, fear of retribution. ${ }^{13}$ Whether the short poem was designed specifically to curry favour with the powerful dignitary is not totally certain. Given the tense nature of the investigation in 1642 into her brothers' applications to become familiares of the Inquisition, it is unlikely that the official concerned would have been directly involved in the case, although we do know that accusations were levelled at the family for attempting to influence the outcome of investigations by entertaining those connected with the inquiries. ${ }^{14}$

A more plausible reason for the presence of the visitor may have been the holding of an auto de fé in Llerena (perhaps alluded to in the reference to his 'cruel trabajo'). The Inquisition archives record several autos in the mid-seventeenth century, including two held in December 1648 and December 1649 at the Convent of Santa Clara, where the poet's two aunts were nuns. ${ }^{15}$ The visiting Inquisitor may also have travelled to Llerena as part of the investigation ordered into the activities of the local tribunal, which had come to the attention of Madrid due to its internal disputes. ${ }^{16}$

\footnotetext{
13 'Inquisition Secretaries were present at all interrogations and kept a legal record of the entire procedure: the declarations of witnesses, the statements of the accused, the torture sessions, the subsequent deliberations and sentences. They alone, apart from the Inquisitors and the public prosecutors, had access to the court's archives. Their functions made them the most important of all the district agents, even more important than the Inquisitors themselves, for the latter could be removed whereas the Secretaries, barring exceptional circumstances, were permanent, embodying as they did the written memory of the Holy Office' (Joseph Pérez, The Spanish Inquisition. A History. Translated by Janet Lloyd [London: Profile Books, 2006], pp. 117-18).

${ }^{14}$ The accusations are set out in the abundant correspondence between officials and the Council of the Inquisition in the 1640s. Lorenzo Gutiérrez de Valverde, a visiting Inquisitor, complained that the governor of Llerena was biased towards the Ramírez de Guzmán brothers and was therefore not a reliable character witness in their application to become familiares: 'El gov[ernad]or de esta ciu[da]d ... favorece a los pretend[ien]tes con exceso hallandose en su casa con muchas cenas y solfeando con sus herm[an]as a el brasero', Archivo Histórico Nacional (AHN), Inquisición, Legajo 2727, 'Carta de Lorenzo Gutiérrez', 24 December 1642.

${ }^{15}$ Details of the autos, in which three people were tried on each occasion, are given in AHN, Inquisición, Legajo 2730.

${ }^{16}$ The procedures surrounding such high-level visits and the detailed investigations conducted by the visiting official are documented by Fernández Nieva, who records two official visits to Llerena: one in 1639 and another in 1643. The local tribunal was instructed to make sure everything possible was done to ensure a comfortable and pleasant stay for the visiting Inquisitor. See Julio Fernández Nieva 'Inquisición
} 
A clearer use by Ramírez de Guzmán of her poetry to influence officialdom is evident in poem XCII, which (like that above) is of interest on account of its historical and sociological relevance. In the piece, the poet seeks to persuade an officer tasked with requisitioning horses for the war effort to exempt the family from the obligation. As members of the local upper classes, the family would have been spared the onerous burden of billeting soldiers imposed on commoners, but - as the poem indicates - not from the duty to contribute the material resources needed to sustain the campaign. ${ }^{17}$ The loss of the horse would disable the family carriage, ${ }^{18}$ with serious consequences for dayto-day activities, including social calls, a prospect which led the poet to pen a complaint at the 'tyrannical' measure. ${ }^{19}$ Ramírez de Guzmán appeals to the officer's sense of gallantry in her bid to have the family spared the hardship of losing the horse. As in many of her décimas, the closing lines sum up the predicament in the form of a witty pun:

\section{Apelo de vuestro enojo}

a vuestra galantería,

que parece tiranía

dejarnos el coche cojo.

Cuando es tan corto el despojo,

interactiva. Inquisición e inquisidores llerenenses en los siglos XVI-XVII', Revista de Estudios Extremeños 56.1 (2000), 161-91.

${ }^{17}$ A valuable account of the financial burden of the war on Extremadura's towns and individual citizens is given in Lorraine White, 'War and Government in a Castilian Province: Extremadura 1640-1668', (unpublished doctoral thesis, University of East Anglia, 1985), particularly chapter 10. Although there is no direct criticism of the war, the poem may well reflect discontent on the part of the civilian population, which 'looked upon war as an intrusion of central government into their lives, and as an attack on their local privileges' (p. 365).

${ }^{18}$ In 1615 , not without controversy, the family had received permission from Llerena council to occupy part of the town wall to build an extension to house the family carriage (Archivo Histórico Municipal de Llerena, Libro de Acuerdos desde 1614, fol. 131 ${ }^{\mathrm{v}}$ ).

${ }^{19}$ The importance of access to a carriage for women's social life is recorded by Jerónimo de Cáncer in a décima in which he asks to borrow one from a friend to take his wife to the river for the day. According to the poet 'todo el verano me ha muerto | por coche mi matrimonio'. In his commentaries on a second décima by Cáncer on the same theme, González Maya notes that riding in a carriage 'era la pasión femenina de la época. El frenesí de las damas por pasear en coche (carruaje) y el afán de los galanes por complacerlas, era general' (Cáncer, 2007: 331). 
mas se logra en perdonallo;

pero si queréis llevallo,

yo quiero que no ignoréis,

que en un potro nos ponéis

si nos quitáis el caballo. (XCII, 1-10)

Whether an appeal from a woman in such deferential terms, including the playful use made of the language of love ('apelo/galantería/despojo') and emphasis on the requisitioner's decision-making powers, achieved its intended purpose is anybody's guess. However, as an example of the use of poetry as a negotiating space to secure an outcome for the family, the request constitutes an interesting facet of Ramírez de Guzmán’s writings. ${ }^{20}$

If the sociohistorical value of the two décimas discussed above is clear, it is even more so in the longest extant poem by Ramírez de Guzmán. Of her occasional poems marking events of public significance, the poetic account of Llerena's celebrations of the birth of Prince Felipe Próspero in 1657 is arguably the most important for several reasons, not least its documentary value. It is surprising that, compared to her portrait poems and a small number of her satirical pieces, virtually no critical attention has been paid to this poem, one of two in her surviving collection written in the coplas de pie quebrado metre.

Before discussing the 368-line description of the fiestas staged by the city to celebrate the birth of the ill-fated Prince, who died shortly before his fourth birthday in November 1661, it is worth dwelling briefly on the importance of the sub-genre of Relaciones of official festivities. Commemorations of public occasions, particularly

\footnotetext{
${ }^{20} \mathrm{I}$ am grateful to Aránzazu Borrachero for drawing my attention to this aspect of the poem.
} 
royal events, played a crucial role in seventeenth-century Spain. An excellent vehicle for official propaganda, they were regularly exploited by the authorities, who often combined the religious and the profane in an attempt to regulate and control the diversions of the populace. ${ }^{21}$ Just as religious celebrations such as Corpus Christi or canonisations of saints afforded the Church an ideal pretext to advance its cause, victories in wars, royal marriages and births, visits by foreign royals and other public occasions gave the Crown and its representatives the perfect opportunity to reinforce their influence across the country. Critical interest in this neglected aspect of Spanish literature has increased noticeably in recent decades and has included several monographic works. ${ }^{22}$ Ferrer Valls is among those to have underlined the importance of such accounts: 'Las relaciones, numerosísimas en el Siglo de Oro, son el mayor documento que hoy en día poseemos para hacernos una idea cabal de las dimensiones que adquiere la fiesta en el Siglo de Oro y de sus pautas de organización' ${ }^{23}$

Due to its dynastic significance, the birth of Felipe Próspero, eleven years after the death of the previous heir to the throne (Baltasar Carlos), was a particularly joyous occasion for Philip IV and was duly marked by lavish celebrations at home and abroad, with nobles and dignitaries competing to stage the most impressive festivities. ${ }^{24}$ The long-awaited arrival of the Prince, who is the subject of one of Velázquez's most

\footnotetext{
${ }^{21}$ As Barrionuevo aptly noted 'bien son menester estos divertimentos para poder llevar tantas adversidades' (Jerónimo Barrionuevo, Avisos de Don Jerónimo de Barrionuevo (1654-1658), ed. by Antonio Paz y Melia, 2 vols. (Madrid: Atlas, 1968-69), II, 51. On the dirigiste aspects of such spectacles, particularly their function as distractions from pressing social concerns, see Hernán Vidal, 'Aesthetic Categories as Empire Administration Imperatives: The Case of the Baroque', in Hispanic Baroques, ed. by Spadaccini and Martín-Estudillo, pp. 20-51 (p. 40).

${ }^{22}$ See, for example, María Cruz García de Enterría, (ed.), Les "relaciones de sucesos" (canards) en Espagne (1500-1750) (Alcalá de Henares: Servicio de Publicaciones de la Universidad de Alcalá, 1996) and Juan Carlos Izquierdo Villaverde, 'Las relaciones de fiestas en verso en torno a Mariana de Austria en la Biblioteca Nacional de Madrid', in Actas del II Seminario de Relaciones de Sucesos (A Coruña, 1315 de julio de 1998), ed. by Sagrario López Poza and Nieves Peña Sueiro (Ferrol: SIELAE, 1999), pp. 175-186.

${ }^{23}$ Teresa Ferrer Valls, 'La fiesta en el Siglo de Oro: en los márgenes de la ilusión teatral', in Teatro y fiesta del Siglo de Oro en tierras europeas de los Austrias, coord. by José María Díez Borque (Madrid: SEACEX, 2003), pp. 27-37 (29).

${ }^{24}$ Musical tributes marking the birth included Calderón's El Laurel de Apolo, staged on 4 March 1658, which was one of the first works to be given the name 'zarzuela'.
} 
famous portraits, was the cue for numerous celebrations in his honour, many of which are recorded in Relaciones that offer a luxury of detail on the fiestas themselves and peripheral events such as certámenes and justas poéticas. ${ }^{25}$ Many plays were also commissioned to mark the auspicious occasion.

In Extremadura, where the war with Portugal was still being fought (as the eulogy for the Duke of San Germán, discussed above, indicates), the celebrations appear to have been more muted, perhaps due to simmering resentment at the monarchy for the destruction and inconvenience caused by the conflict. Very few surviving documents record official celebrations of royal or religious occasions during the war years in the region. One of these, a Loa a las fiestas de la boda de nuestra Señora en la ciudad de Coria. Año 1652 by Joseph Álvarez de Jaque y Manzanedo, is of interest because of its singular combination of the purely celebratory aspects and multiple references to Coria's heroic resistance in the face of attempted invasion by the Portuguese. Through one of the characters, Embidia, the author raises doubts concerning the appropriateness of public celebrations given the military conflict: ‘¿pues cómo es posible, cómo | que en medio de ahogos tantos | se introduzga el regocijo | donde debiera el llanto?,26

However, several towns and cities in Extremadura did mark the occasion. The archives of Badajoz record the decision by the local authorities to hire a well-known theatre company to perform 'cuatro comedias con ocho sainetes nuevos y una loa para

\footnotetext{
${ }^{25}$ Among the interesting records is one by Francisco de Roys y Mendoza, Relación de las demostraciones festivas de religion, y lealtad que celebró la insigne Vniversidad de Salamanca. En el deseado y dichoso nacimiento del Principe nuestro Señor D. Felipe Prospero (Salamanca: Sebastián Pérez, 1658), which runs to 472 pages and provides a wealth of detail on the festivities and the accompanying certámenes, with a full account of the verses submitted. A jocular romance of almost 600 lines by Diego de Vera y Tassis describes the different events (bullfights, dances, máscaras, etc). The poem was deemed so worthy that the competition judges decided no other entries were needed for the category (p. 442). For details of other celebrations in Spain, see Alberto Río Nogueras (ed.), Relación de fiestas que la ciudad de Huesca de Aragón ha hecho al nacimiento del Príncipe Nuestro Señor D. Felipe Próspero de Austria, ed. facsimilar de la de Huesca, s.i., 1658 (Huesca: Ayuntamiento de Huesca, 1994) and Consuelo Gonzalo García, 'Sucesos mayores en impresos menores: el nacimiento del Príncipe Felipe Próspero (1657)', Rivista di Filologia e Letterature Ispaniche 2 (1999), 133-58.

${ }^{26}$ Madrid, Biblioteca Nacional (BNM), Ms 3917, fol. 28v. Annotations in the manuscript indicate that the loa was staged soon after in Badajoz also.
} 
festejar el nacimiento del Príncipe' although a subsequent contractual dispute caused the cancellation of the performances. ${ }^{27}$ It can be safely assumed that, as a flourishing provincial city and home to a sizeable community of writers, ${ }^{28}$ Llerena would have been no different to other parts of the nation in organising poetic events to mark the occasion and it is a matter of regret that no evidence of these has survived. As for the actual fiestas, the unusual Relación by Ramírez de Guzmán constitutes the only surviving information and the importance of the piece is therefore unquestionable.

The poem, which is followed in Ms 3917 by another piece on the festivities staged in Madrid in honour of the newborn Prince ${ }^{29}$ (suggesting some attempt at thematic grouping by the compiler and also that Ramírez de Guzmán’s account was probably known beyond Llerena), was surprisingly dismissed by Alenda y Mira as an irrelevant contribution to the historical records of the public celebrations of the period. ${ }^{30}$ However, it is important on several counts, not just for its historical value but also because it is one of relatively few poems of its kind to have been written by a female hand. The extent of female participation in Relaciones has not been fully established but it was certainly much less common than that of men. ${ }^{31}$ Despite Voros's assertion that women's participation was rare, there were notable exceptions: in addition to Ana Caro Mallén and Ramírez de Guzmán, other female writers who composed poetic records of

\footnotetext{
${ }^{27}$ The approval of the budget for the hiring of the Mariana Vaca Company is dated 9 January 1658 but the company raised its fee to reflect the additional dangers posed by the proximity of the front of the war with Portugal. For details see Fernando Marcos Álvarez, Teatro y vida teatral en Badajoz. 1601-1700 (London: Tamesis, 1997), p. 42.

${ }^{28}$ For details of other local poets and their activities, see Karl McLaughlin, 'Catalina Clara Ramírez de Guzmán: Llerena's Academy Poet?', Bulletin of Spanish Studies (forthcoming).

${ }^{29}$ This anonymous piece is unusual in its direct criticism of the authorities' attempts to capitalise on the occasion: 'Pero que a costa del pobre | quiera la Villa lucir $\mid$ y de trabajos agenos $\mid$ haga fiesta para sí | de esto sí que se me da a mí'. Like Ramírez de Guzmán, the author criticises the poor horsemanship of the participating riders: 'Pero que de los jinetes | no aya nada que decir | sino que entre quatro pares $\mid$ no hubo ningun paladín | de esto sí que se me da a mí' (BNM Ms 3917, 84v).

${ }^{30}$ See Jenaro Alenda y Mira, Relaciones de las solemnidades y fiestas públicas de España, vol. I (Madrid: Rivadeneyra, 1903), p. 338.

${ }^{31}$ Sharon D. Voros, 'Relaciones de fiestas: Ana Caro's Accounts of Public Spectacles', in Women in the Discourse of Early Modern Spain ed. by Joan F. Cammarata, (Florida: University Press of Florida, 2003), pp. 108-32.
} 
public festivities included Ana Abarca de Bolea, whose 'Romance a la procesión del Corpus en Sayagués' in her Vigilia y Octavario de San Juan Bautista contains a detailed description of the procession, its participants and the dances and other elements of the celebrations. ${ }^{32}$

Moreover, the long account by Ramírez de Guzmán stands in clear contrast to the ornate eulogies of similar festivities found in the poetry of seventeenth-century female writers, such as Aragon's Eugenia Buesso, author of several Relaciones en verso of royal and religious occasions. ${ }^{33}$ Far from extolling the lavish celebrations with the customary hyperbole (aiding the official propagandist line), the Llerena author gives free rein to her humorous vein and the account offered, perhaps lacking the subtlety of some of Quevedo's satirical descriptions of similar celebrations, undermines the solemnity of the occasion with a more prosaic description of the proceedings.

Ramírez de Guzmán makes clear from the outset that her 'portrait' of Llerena's celebrations is going to be different: instead of a composition aimed at eliciting public praise, hers is addressed to an unnamed woman friend who was unable to attend in person due to absence. The poem opens thus:

Ya que no viste las fiestas, en rasgos he de copiarlas, si es que no quieres verlas ni pintadas. (CIII, 1-4)

\footnotetext{
32 The poem, narrated by a male character, is addressed to a friend and adopts a similar tone in places to that used by Ramírez de Guzmán. It concludes as follows: 'Mas, Pascual, al otro año, | si es que entonces se me acuerda, | te acabaré de contar | esta procesión tan larga'. See Ana Abarca de Bolea, Vigilia y Octavario de San Juan Bautista, ed. by María Ángeles Campo Guiral (Zaragoza: Instituto de Estudios Altoaragoneses, 1993), pp. 399-407.

${ }^{33}$ For details of Buesso's Relaciones, see María del Carmen Marín Pina, 'Eugenia Buesso, cronista en verso de la entrada de Juan José de Austria en Zaragoza (1669): un texto recuperado', Mujeres en la literatura. Escritoras, IV, No. 19 (Mexico City: Destiempo, 2009), pp. 60-81.
} 
A note added to the end reinforces this private tone and the request not to divulge the contents indicates her awareness of the possible repercussions of her poem, which, it appears, was not intended for public consumption: 'Amiga, bien disculpa el romance mi resistençia, y su precepto arrastra mi desconfiança. Temo que van las coplas quebradas, y vuelvan rotas. Perdone la prosa, que romance tan largo no excusa dedicatoria. No pase original a otra mano.'

Commencing with the offering of prayers to the city's patron, the Virgen de la Granada, the proceedings got under way with a eulogy of the heir to the throne by a local dignitary:

Con afecto, el orador

se desató en alabanzas

y de que el niño sea grande

dio esperanzas. (CIII, 21-24)

The festivities lasted an entire week but, as we learn from the poem, were marred by bad weather:

Echó el capote la noche

y montó en cólera el agua,

y se anegara la fiesta

si no nada. (CIII, 93-96) $)^{34}$

The narration of the sequence of events underlines the importance of the local gremios, who paraded through the city mounted on horses, donkeys and floats and

\footnotetext{
${ }^{34}$ The tone used in the references to the downpours is reminiscent of Quevedo's watery allusions in his description of the 'Fiesta de toros, con rejones, al Príncipe de Gales, en que llovió mucho'. See also the witty references by the Count of Salinas in his redondillas on a rain-threatened masked ball hosted by the Count of Gondomar in October 1614 (Diego de Silva y Mendoza, Conde de Salinas, Obra Completa I. Poesía Desconocida, ed. by Trevor J. Dadson (Madrid: Real Academia. Española, 2016), p. 31.
} 
whose hierarchy is reflected in their order of appearance in the processions: millers, tailors, shoemakers, ironsmiths, merchants, tanners, etc.

The highlight of the celebrations was a bullfight featuring twelve fearsome bulls from Badajoz ('doce tigres se lidiaron | que tributó Guadiana', 221-22), ${ }^{35}$ although equally popular with the public were the sortijas (running at the rings) in which horsemen galloped down the crowd-lined streets to spear hanging rings with their lances. Popular also was the spectacle of the riders competing in the game of estafermo (quintain), ${ }^{36}$ as well as the masquerades and mojiganga (a variation on the masquerade in which people dressed in animal costumes). ${ }^{37}$ Another game of mediaeval origin, the mock-fighting of the juego de cañas (jousting with canes), ${ }^{38}$ was also staged for the crowds in Llerena, which was decorated in its finest colours for the historic occasion.

From one of the most prized vantage points in the city, the upper windows of the family house in the 'portal del pan' on the main square, Ramírez de Guzmán would have enjoyed a magnificent view of the proceedings. ${ }^{39}$ However, this privileged view was used not for a hyperbole-filled account of the fiestas of the type which was common currency in the public occasion literature of the day, but to poke fun at the participants and underline the lack of grace and dexterity displayed in the tournaments,

\footnotetext{
${ }^{35}$ Narrations of bullfights were a popular subject in the poetry of the period. In addition to the many formalised descriptions, witty variations were common and included Pantaleón de Ribera's romance entitled 'Relazion de la fiesta de toros que se hizo a 26 de junio de quien no las bio y las tubo escritas antes que se yzieron' (BNM Ms 3773, fols. $45^{r}-48^{v}$ ). The poem is similar in tone to the one by Ramírez de Guzmán and, like it, is addressed to one individual: 'Marica pues no has querido | Ber los toros por olgarte $\mid$ decuelgate con oyrlos $\mid$ de la lengua de mi Romanze' (1-4).

36 'El juego de estafermo tomaba su nombre de un muñeco giratorio, en cuyo escudo golpeaban con su lanza varios corredores a caballo. Si no lo hacían con rapidez, volvíase el estafermo y les sacudía las espaldas con unas bolas o saquillos de arena'. See José Deleito y Piñuelo, El rey se divierte, 2nd ed. (Madrid: Espasa-Calpe, 1989), p. 182.

${ }^{37}$ The popularity of these and other festive games and events of the period is recorded by many foreign authors. See, for example, John Dunlop, Memoirs of Spain during the Reign of Philip IV and Charles II: From 1621 to 1700. Vol. 2. (London: Whittaker and Company, 1834), pp. 479-81.

${ }^{38}$ A contemporary of Ramírez de Guzmán, Isabel de Aguiar, also refers to the game in her poem entitled 'A una librea que saco en un juego de cañas un cavallero guarnecida de plata y las espadas sin guarnicion' (BNM Ms 3771, fol. 80). For a detailed treatment of the importance attributed to the game of canes, including for social relations, see Javier Irigoyen García, Moors Dressed as Moors. Clothing, Social Distinction, and Ethnicity in Early Modern Iberia (Toronto: University of Toronto Press, 2017).

${ }^{39}$ It is worth noting that, several years later, in 1674, Ramírez de Guzmán inserted a clause in rental contracts for the house guaranteeing access to one of the high windows during festivities and bull-fights.
} 
including their unsuccessful efforts to behead live geese hung from a wire (49-56). ${ }^{40}$ The mocking aim, signalled explicitly in the second stanza, where the friend is warned to prepare herself for a 'romance de mojiganga', is foregrounded regularly in the poem through direct references by the author to her intentions, including an appropriate lexical play in the case of the tanners:

Del gremio de curtidores

mormurar se me olvidaba,

y mi musa ha de zurrarles

la badana. (CIII, 341-44) ${ }^{41}$

Among the targets ridiculed in the witty portrayal are the tailors ('fue desastre su fiesta', 69), whose unimpressive efforts to hit the quintain are recorded as follows:

Con un estafermo, airados,

anduvieron muy a malas

porque tragaban talega

sin poner lanza $[\ldots]$

Insensible, aunque no inmóvil,

se burla de ellos la estatua

que a moro muerto cualquiera

da lanzada. (CIII, 73-76, 81-84) $)^{42}$

\footnotetext{
${ }^{40}$ Compare, for example, the treatment of the participants with that offered in a poem by Leonor de la Cueva, which is discussed by Fox (2004: 40): 'she acknowledges a young man's success at toros y cañas. This dangerous game, reserved for the wealthy upper classes, provided opportunities for display and advancement for the successful contestants. In writing of such events, Cueva inscribes herself into the privileged, provincial circle, and shows that she is knowledgeable about and participates in the lives, interests and pastimes of the important men of her region'.

${ }^{41}$ The frequent self-references in the poem include indications that the poet was aware of the reaction her account might trigger: 'Ya dirán los escribanos | que mi pluma es mal cortada | y una causa le harán | sin otra causa' (185-88).

${ }^{42}$ Unlike Ramírez de Guzmán, Ana Abarca de Bolea's character Ginés is reluctant to speak ill of the 'oficios' who took part in the Corpus Christi procession in Zaragoza, perhaps due to their local influence:
} 
Each guild's contribution to the festivities is conveyed with appropriate vocabulary: the blacksmiths 'hiceron torno, volviéndose | a sus casas' (147-48) on concluding their participation in the procession, while the shoemakers began theirs 'con mejor pie' although the initially positive impression proved short-lived. The arrival of the scribes is described as follows:

Un "sepan cuantos" nos dieron

de lucimiento sus hachas, tomando carta de pago

de su gala. (CIII, 193-96)

Apart from the merchants, whose participation is praised as 'la mejor fiesta en inventivas y traza' (157-58), virtually the only group spared from the parodic descriptions are the city's women, who observed the proceedings from the lavishlydecorated balconies partially covered as their appearance in public demanded: ${ }^{43}$

Cada balcón era un cielo,

si una estrella cada dama,

y hubo a la tarde luceros

de la mañana.

Bellezas de manifiesto, en deidades se disfrazan, hurtándole el disimulo a las tapadas.

'De los oficios, no digo, | que mal oficio tuviera | quien fuera su relator | en una Villa como ésta' (1993: 404).

${ }^{43}$ A 'tapada' appears elsewhere in the poem also, voicing ridicule at the horsemen: 'Viendo errar la escaramuza | burlándose una tapada | dijo: "Otra pata le nace | con que se escapa".' (53-56). 
Pero a pesar del embozo,

en conocidas ventajas,

quien la gala no llevó

llevó la gala. (CIII, 225-36)

Viewed in purely artistic terms the long Relación is not the most accomplished poem in the collection but is nonetheless of considerable interest as a piece of historic literature for the account offered of the festivities, including the detailed descriptions of, for example, the attire of the sortija competitors. Moreover, the clearly private nature of the composition is a rare exception to the very public expressions of similar festivities in Spain. If the authorities were hoping that Ramírez de Guzmán might assist their cause by extolling the celebrations, they could not have been more wrong. Her natural tendency for wit ensured she produced a humorous and, in various places, mocking rendering which undermined both the official central discourse and the solemnity of her home city's most important event for several decades. As already stated, the city fiestas in honour of the newborn Prince are not recorded in the Llerena archives, let alone in published form. Ironically, what was intended to be a private poetic description of a very public celebration is the only surviving record of the historic occasion and although not intended for publication has become accessible to a much larger audience than its author could ever have imagined when sending the piece to her unnamed friend.

\section{Private occasion poetry}

In contrast to the above commemoration of a major public occasion stands a group of poems that record occasions and situations of a more private nature, associated with Ramírez de Guzmán's everyday relationships and her family. Like the Felipe Próspero poem, one such piece concerns the birth of a child. The long ballad on the 
subject of the unborn baby of a friend ('Otro romance a la preñez de una dama', CXIV) merits inclusion in this examination of her occasional verse on account of its relative rarity in the literature of Extremadura and Spain and for the glimpses it provides of the largely taboo subjects of pregnancy and childbirth. Apart from a small number of prescriptive tracts offering instructions on how to manage the body in its gravid state and the well-known description by Quevedo of fertilisation, pregnancy, miscarriages and abortions in his philosophical treatise Providencia de Dios $(1641),{ }^{44}$ the themes of childbirth and maternity were far from common in early modern Spanish literature, an absence especially pronounced in relation to poetry. ${ }^{45}$ Despite occupying much of women's lives and being a very visible phenomenon, pregnancy appears to have been largely invisible in terms of cultural representation and was confined to the purely private or domestic sphere.

The 184-line ballad, one of the longest of Ramírez de Guzmán's poems, fits this private/domestic context to a large extent, although in her personal address to the unborn child she broadens the scope to include laudatory references to the baby's family antecedents and, as we shall see, to comment on society's perception of female children. From biographical inferences in the piece it is almost certain that the child-to-be's uncle was Juan de Almezquita, a member of one of Llerena's most prominent families and the

\footnotetext{
${ }^{44}$ For a discussion of Quevedo's treatment of these subjects, see José J. Tato Puigcerver, 'Embarazo, parto y primera infancia en la obra de Francisco de Quevedo y Villegas (1580-1645)', Espéculo: Revista de Estudios Literarios, 38 (2008) <http://www.ucm.es/info/especulo/numero38/embaque.html $>$ [Accessed 05/12/2017].

${ }^{45}$ Exceptions deserving mention include Pantaleón's de Ribera's ballad to the unborn child of his protector, the Duke of Lerma, which opens 'Conde mi señor de Ampudia | el que sin aver nacido | sois en el vientre materno | aun antes Grande que vivo'. The style and tone of the humorous piece offer some similarities with the poem by Ramírez de Guzmán, particularly the allusions to maternal cravings, the advice to remain in the womb and various references to gender preference. See Anastasio Pantaleón de Ribera, Obras, ed. by Rafael de Balbín Lucas. 2 vols. (Madrid: CSIC, 1944), I. pp. 91-98. Although not dealing directly with pregnancy, a small number of poems to the infant child of patrons (essentially commemorations of christenings and birthdays) feature in the occasional verse of Sor Juana Inés de la Cruz. Other poetic accounts of pregnancy and childbirth include highly implausible pieces such as the bizarre romance by Fernando Álvarez, the 'Relacion muy verdadera, en que se da cuenta de vna muger natural de Seuilla, que en tiempo de doze años que ha que es casada ha parido cincuenta y dos hijos ...' (Seville, 1633), which can be viewed in the wider European context of the literary treatment of superfetation, a subject which features also in Shakespeare's The Winter's Tale.
} 
local poet with whom Ramírez de Guzmán exchanged verses on the subject of her novella, El Extremeño $\left(\mathrm{CIX}^{\mathrm{b}}\right)$. The poem is replete with metaphors and plays on words concerning aspects relating to pregnancy, ${ }^{46}$ which, although depicted as leading to a joyous outcome for the parents, is described in unflattering terms in places. The baby, 'hecho un vinagre' due to his mother's 'damerías', is temporarily accommodated 'entre panças y cuajares'; the pregnant bump is an abscess ('postema'); and the actual act of childbirth is conveyed in similarly unromanticised terms as "cuando a los pies te arrojare'. For its part, morning sickness, a subject rarely treated in the literature of the day, is alluded to in a witty conceit based on the canonical descriptions of hair which are an ever-present feature of Ramírez de Guzmán's portrait poems:

Si en el mar de tu cabello

acedías se criasen,

aunque a vómitos provoque,

yo sé que no ha de trocarte. (CXIV, 53-56)

Like Quevedo in his Providencia de Dios, Ramírez de Guzmán also enumerates childhood illnesses, including measles, smallpox, worms and other ailments, all of which are warded off with appropriate plays on words. The child need not, for example, fear epilepsy:

Ni temas la alferecía, aunque te alistes infante, que a ti no se han de atrever achaques de capitanes. (CXIV, 25-28)

\footnotetext{
${ }^{46}$ The allusions include conventional puns on cravings ('ponle a tu madre antojos; | verá que quieres mudarte', 77-78) and a number of contrived references which are less understandable to modern-day readers, for example, the mention of a famous sword maker of the period: 'aunque la que traes en çinta | es mejor que la de Juanes' (95-96).
} 
The baby's 'imprisonment' in his mother's womb is conveyed humorously as an 'aprieto tan grande', 'piadoso hospedaje' and 'calaboço amable'. ${ }^{47}$ The wordplay extends also to the physical description of the future baby, whose features are rendered with appropriate noble analogies, also in the style of the portrait verse canons:

Tus cejas, al Duque de Arcos

dirá que son semejantes;

al conde Claros, tus ojos,

y al duque de Alba, tus carnes. (CXIV, 109-12)

The witty ballad is full of references that facilitate the piecing together of the family background of the baby-to-be. In addition to explicit allusions to the lineage of the family, through the mentions of the surnames Mendoza, Alba, Paz, Almezquita, etc, we learn that the baby's father is the 'alcalde y alguacil mayor' in Valencia de la Torre, a circumstance which is seized upon to warn the baby to remain in the womb for the full term or risk paternal wrath and retribution:

Si intentas quebrantamiento

de la prisión en que yaces,

te cumplirá de justicia,

a pedimento de parte. (CXIV, 85-88)

The importance of a full-term pregnancy is alluded to in several places in the poem, perhaps as an antidote to the past deaths of ill-fated siblings:

\footnotetext{
${ }^{47}$ The 'sweet captivity' paradox is recurrent in the poetry of the Ramírez de Guzmán, particularly in the nature poems: the cold water of the spring is a 'prisión tan rica' which prevents the flowers from escaping (XVI, 51). Elsewhere, her sister Antonia's eyes are described as pirates who enslave all who see her: 'piratas ellos | que a cuantos los ven conducen | a tan dulce cautiverio' (XXVIII, 30-32).
} 


\section{Escarmienta en tus hermanos,}

que son tan orates fratres

que adrede se van al Limbo,

por no dejar gobernarse. (CXIV, 41-44)

A last and important aspect of this poem on the theme of pregnancy and childbirth is the allusion to prevailing cultural dictates concerning the value of children depending on their gender. Although in the closing section both possible genders of the future baby receive equal treatment ('A Periquillo-Francisquilla $\mid$ en el vientre de su madre', 177-78), only 24 of the previous 176 lines contemplate the possibility that the child will be a girl. Throughout the rest of the poem, positive desires and an optimistic outlook are expressed for the baby, provided he is a boy, an assumption evident from the first word of the ballad, in which he is referred to as 'Periquillo el de Valencia', an allusion to the likely name of a male child (Pedro). ${ }^{48}$

However, the closing strophes raise the possibility that the unborn baby may turn out to be a girl and there is more than a hint from Ramírez de Guzmán that, due to social prejudices, this may be the less favoured option for the family. ${ }^{49}$ Whereas Periquillo will be the object of maternal and, in particular, paternal love and affection (his father is 'para todos liberal | y para ti sera amandi'), the baby girl is advised to cover up in case her arrival triggers resentment on the part of her parents:

\footnotetext{
${ }^{48}$ The opening line, a good example of intertextuality in Ramírez de Guzmán's verse, would certainly have been familiar as a local play on a fictitious character made popular by, among others, Jerónimo de Cáncer, who composed a jácara beginning 'Periquillo el de Madrid | aquél que cuando acaricia | le hace a su dama mil fiestas | con otras tantas vigilias' and an entremés entitled El Sordo y Periquillo el de Madrid, first staged in 1649 to mark the arrival in Madrid of Mariana of Austria for her marriage to her uncle, Philip IV.

${ }^{49}$ Allusions to the positive and negative connotations of the gender of a child were already common in Spanish literature. In Act V of La Celestina, Sempronio uses the expression 'Dime si tenemos hijo o hija' in asking Celestina if she brings good or bad news. 'Tenemos hijo o hija: frase con que se pregunta en los negocios dudosos, por el buen o mal estado de ellos' (Diccionario de Autoridades). Similarly, the expression 'mala noche y parir hija' was common in the seventeenth century to denote disappointment at the outcome of painstaking efforts.
} 
Y si fueras Francisquilla

ven en manto por taparte

y, por si acaso, enojados

te envïasen a la calle. (CXIV, 153-156)

Although the negative connotations are tempered in subsequent references, for example, the likelihood that the girl will be beautiful given her parents' physical attributes ('Fea, no es posible, siendo | hermosa de padre y madre', 165-66), the distinction drawn between the two sexes in terms of the social repercussions of gender is nonetheless striking and one wonders whether Ramírez de Guzmán herself shared this discriminatory view in expressing the desire for the baby to be male: 'Güela, pues, la casa a hombre' (81).

Gender distinction as a social reality can also be said to underpin the group of poems marking occasions and situations associated with Ramírez de Guzmán’s family life. A substantial number of her poems can be viewed as domestic sphere variants of the occasional poetry marking occasions of public significance such as the birthdays and weddings of patrons or rulers. In contrast to Sor Juana's poetic commemorations of aspects of the very public lives of the Countess of Paredes and her husband, Ramírez de Guzmán's poems on similar themes focus almost entirely on the private realm of her family. The large number (approximately 20) dedicated to her parents and siblings is a distinctive feature of her poetry, indicating that she may have viewed her verses as mechanisms for consolidating and reinforcing family bonds. She is exceptional among the authors of her day in the quantity of verses dedicated to or concerning members of her own family and on all manner of family occasions, ranging from birthdays and weddings to domestic accidents. The poems largely constitute celebrations of family 
love and are filled with expressions of devotion and affection, while at the same time providing useful glimpses of the social reality of the day.

A revealing distinction can be observed in the treatment of the male and female members of the family. The occasions that serve as the pretexts for the poems to the poet's father and brothers usually involve their physical absence, including her father's trips to Madrid on official business (which the poet takes advantage of to request items of female fashion), ${ }^{50}$ her brother Pedro's absences, presumably also in connection with his many official duties as an administrator (XVII, XLI), and her other brother Lorenzo's spell behind bars for disobeying the orders of his ecclesiastical superiors to cut his long hair (CX).

Conversely, the references to the female members of the family tend to record presential occasions. ${ }^{51}$ In contrast to her husband, Isabel de Guzmán, the poet's mother, is virtually invisible in her daughter's poems. She makes only one direct appearance: as the subject of an affectionate piece (XXIX) in which she is admonished for her devotion to her needle-work, despite its harmful effects on her sight. The rebuke, expressed in playful language (the allusion to her mother's squinting, for example), may carry a more serious undertone as a reflection of Ramírez de Guzmán's views on the traditionally subservient role of the mother in the male-dominated home. Doña Isabel is chastised by her daughter for her limited occupations, which are confined to domestic chores:

Tus ojos forman querella

\footnotetext{
${ }^{50}$ XII: 'Pidiendo el autor a su padre una almilla'; LXXXIX: 'Pidiendo la Autora a su padre que la trujese un manto, estando en Madrid'. In XCV, the poet playfully voices concern at her father's health after he suffered gout on his return from a trip to Madrid: 'No habrá sido inadvertida | la inquietud que me alborota, | temiendo que agüe una gota | el gusto de la venida' (7-10).

${ }^{51}$ The contrast between the treatment of the male and female members of the family is also noted by Kaminsky in her brief comments on the poet in her anthology: 'Doña Catalina Clara was a prolific writer whose family comes to life in her verse [...] These domestic poems bear witness to the traditional gender roles of the Spanish aristocracy of the era. The mother and four daughters composed a society of the home while the men went out into the world for political or military purposes'. See Amy Kaminsky (ed.), Water Lilies/Flores de Agua. An Anthology of Spanish Women Writers from the Fifteenth through the Nineteenth Century (Minnesota: University of Minnesota Press, 1996), p. 383.
} 
ponderando que es rigor

amar tanto la labor

que ciegues, Silvia, por ella.

Pero como sólo ella

te entretiene (cosa es 1lana),

tomaré de buena gana

(en esta fineza advierte),

sólo para entretenerte,

que me zurzas la badana. (XXIX, 1-10) ${ }^{52}$

The portrayals of the Ramírez de Guzmán sisters also reflect gender roles in society. They receive essentially stereotyped mentions as the subjects of stylised portraits in verse, celebrations of birthdays - an occasion not marked by the poet in the case of her two brothers - and, in a domestic variation of the Petrarchan spilling of blood caused by a rose-pricked finger, references to the occasional accident, such as the eye injury sustained by Ana Rosalea. ${ }^{53}$ Despite their manifest echoes of conventional poetic representations and their clearly domestic focus, which is explicitly acknowledged by the author, ${ }^{54}$ the poems are not devoid of interest. Although spoilt at

\footnotetext{
52 Interestingly, Cruz views this poem as reflecting a particularly strained relationship between mother and daughter: 'Aunque la relación madre-hija llega hasta la madurez, sus poemas evidencian sensiblemente una separación entre las dos. La siguiente décima compara la inatención de la madre en su hija con su demasiado interés por la costura, que le ha afectado la vista [...] Ramírez de Guzmán le reprocha su desamor al utilizar el juego de palabras entre 'zurzir la badana' coser un cuero fino, con 'zurrar la badana', expresión que significa maltratar de obra o de palabra'. See Anne J. Cruz, 'La búsqueda de la madre. Psicoanálisis y feminismo en la literatura del Siglo de Oro', in Historia silenciada de la mujer: la mujer española desde la época medieval hasta la contemporánea, ed. by Alain SaintSaëns (Madrid: Editorial Complutense, 1996), 39-64 (pp. 58-59).

${ }^{53}$ CXIII: 'A una hermana que se hirió con un garabato', which like the poem to doña Isabel deals with the health risk (interestingly, also to the victim's eyes) arising out of a domestic pursuit. The poem is of lexicographical interest also for its multiple references to 'garabato' as a type of hook used to hang kitchen scales.

${ }^{54}$ For example, in the poem marking the birthday of Beatriz: 'por ser aplauso casero | puede entre hermanas pasar; | lo vulgar le perdonaremos' (CIV, 22-24). The piece ends as follows: 'de la bendición casera. | Muchos días veas d'estos'.
} 
times by infantile word play based on the names of the sisters and the multiple puns derived from the different meanings of 'colgar', ${ }^{55}$ the birthday poems, for example, offer interesting biographical details, especially in the case of Beatriz. ${ }^{56}$ Two references in the poem commemorating her birthday (CIV) allow her date of birth to be fixed in late July (the coincidence of her saint's day with that of St Martha is mentioned specifically in lines 4-5 and the July heat is referred to in line 83), much earlier than her baptism the following April, which is somewhat surprising given the family's track record of ill-fated babies. ${ }^{57}$ The mentions in the same poem of the gifts received by Beatriz (perfumed gloves, comb, slippers, brooch, ear pendant, etc) and to a contemporary hairstyle ('copete') also offer an interesting snapshot of the fashions of the privileged classes of the day.

For its part, the short poem on the wedding of Ana Rosalea (LXXIX) is of interest for the perspective offered concerning the female role: Ramírez de Guzmán refers to her youngest sister as the "dulce posesión"58 of her husband-to-be (who is virtually non-existent in the piece) and expresses her hope that her marriage will produce children, which would be the 'fortuna mayor'.

Other poems recording essentially private as opposed to public occasions give further access to the social reality of the day in provincial Llerena. Many aspects of these verses mirror topics reflected in the work of contemporary authors, such as descriptions of blood-lettings, with the customary hyperbolic references to the female

\footnotetext{
55 Two of the poems (CIV, CXV) dwell extensively on the pun, which is understandable to a modern reader only if the less widely-used meaning of 'colgar' is recalled: 'regalar o presentar a uno una alhaja en celebridad del día de su santo o de su nacimiento. Dícese así porque se hacía esta demostración echando al cuello, a la persona a quien se obsequiaba, una cadena de oro o una joya pendiente de una cinta' (Diccionario de Autoridades).

${ }^{56}$ In the case of Ana Rosalea too, however, allusions in the poems confirm biographical details such as the month of her birth: 'Invidioso del enero | el mayo se desmayó' (CXV, 21-22).

${ }^{57}$ Two Ramírez de Guzmán children had already died in early childhood by the time of the birth of Beatriz in 1616. Catalina Clara was named after one of these, born in July 1611.

${ }^{58}$ The description echoes the views of leading moralists of the day with respect to the respective husbandwife roles, as well as Fray Luis de León's reference in the Perfecta Casada (chapter 13): 'porque no hay joya ni posesión tan preciada ni envidiada como la buena mujer'.
} 
patient's beautiful pallor (XXXV, XXXVI, LXXX), and conventional descriptions of ladies styling their hair (LIV) or in mourning dress (LXXXIII). ${ }^{59}$

Penning poetic accompaniments for gifts was also a fashionable custom in the literature of the period. The titles of several poems by Antonio de Solís - for example, 'A una Dama, que tomaua tabaco, embiandole vn Coco de la India lleno dél'; 'Embiando à vna Dama vn vidrio de Santo Domingo, que auia pedido'; 'Enviando un abanico de porcelana' - indicate he regularly composed décimas to accompany presents for female acquaintances. Occasionally, instead of the gift, Solís would send a poem playfully excusing his non-compliance with the request: 'El abanillo cortado, | tampoco te he de embiar; | Porque te puede matar, | si te dà vn ayre colado' ${ }^{60}$ Jerónimo de Cáncer's poetry includes a décima entitled 'Enviando desde Alcalá una bota de vino moscatel a un amigo suyo' and a romance entitled 'Enviando de sangria a una dama unas naranjas, unos barros y unos ramilletes' (2007: 333). ${ }^{61}$ Verses recording the sending of gifts in Miguel de Barrios' Flor de Apolo include the 'Décima de un galán a una dama que le dio unas flores de con un poco de hinojo' 62 and 'Décima burlesca de José Semáh Arias enviándome un presente de dulces con un candil'. For his part, Góngora penned a number of décimas and letrillas to accompany gifts of food to local nuns. ${ }^{63}$

\footnotetext{
${ }^{59}$ In 'A una dama que trajo mucho tiempo toca en un luto', Ramírez de Guzmán attempts to persuade the lady to end her period of mourning and free her hair from its 'prison'. The poem consists of a series of extended conceits based on words associated with imprisonment (crime, sentence, etc) and closes with an ingenious reference to one of the most feared Inquisition torture methods (a form of waterboarding): ' $y$ hasta averiguar las muertes | le das tormento de toca' (9-10).

${ }^{60}$ For all the poems listed, see Antonio de Solís y Ribadeneyra, Varias poesías sagradas y profanas, ed. by Manuela Sánchez Regueira (Madrid: CSIC, 1968).

${ }^{61}$ According to Deleito y Piñuela, it was common to send a present to a beloved whose blood had been let. The lady would send a blood-stained handkerchief in return. See José Deleito y Piñuela, La mujer, la casa y la moda (en la España del Rey poeta), 2nd ed. (Madrid: Espasa-Calpe, 1954), p. 59.

${ }^{62}$ See Miguel de Barrios, Flor de Apolo, ed. by Francisco Sedeño Rodríguez (Kassel: Reichenberger, 2005), p. 369 and p. 355, respectively.

63 'Enviando dos conejos a una monja, pariente suya'; 'A otra monja, que le había pedido unas castañas y batatas'; 'A dos monjas. Enviándoles una cesta de ciruelas cubierta de unas hojas de laurel'. For these and other gift-themed poems by the same author, see Luis de Góngora, Obras completas, ed. by Antonio Carreira, 2 vols. (Madrid: Biblioteca Castro, 2000).
} 
The custom features prominently in Ramírez de Guzmán’s work, which contains a number of poems reflecting social interaction in the form of the sending of gifts, particularly to female acquaintances. ${ }^{64}$ One décima - 'Inviando unos cabos bordados de plata pasada que, habiéndolos prometido, no fueron muy puntuales' - is a playful apology explaining her delay in sending some decorative needlework as promised:

Esos cabos que desmiente

su tardanza a mi cuidado, bordados van de pasado, y inviados de presente.

Por serviros diligente, hoy mi ingenio liberal echó en ellos su caudal. Decidme por la estafeta que en dibujos no me meta si ese os pareciere mal. (XXXVIII, 1-10)

Elsewhere, verses are used as a humorous reminder to a friend who had forgotten to send a popular, but unpleasant-sounding, cosmetic of the period made from animal bile ('muda de hiel'): ${ }^{65}$

\section{Está tan acreditada}

vuestra liberalidad

que aun la mesma cortedad

\footnotetext{
${ }^{64}$ Not all the gifts were for women, however. The theme of poem LXXXIV is a culinary offering ('huevos hilados') sent by the poet to an unnamed military judge. Like the pieces addressed to the horse requisitioner and the senior inquisition official, the décima might also be interpreted as a conscious use by Ramírez de Guzmán of her poetry for a specific social purpose.

65 The poem is entitled 'A una señora que habiendo prometido a otra una muda de hiel se olvidó de inviarla'. 'Muda: cierta untura que las mugeres se ponen en la cara para quitar dellas las manchas' (Sebastián de Covarrubias Orozco, Tesoro de la lengua castellana o española, Madrid: Luis Sánchez, 1611), p. 1153.
} 
os hace desperdiciada.

Y, así, no faltáis en nada,

si acaso os habéis mudado

de haber la muda mandado:

que no es avaricia alguna,

pues no inviándome una,

muchas hieles me habéis dado. (LVII, 1-10)

The use of various types of 'afeites' by Spanish women, particularly those from the affluent classes, is well documented and was frequently mentioned in the writings of foreign visitors to Spain. A target for criticism by moralists, ${ }^{66}$ the cosmetic custom also prompted satires against women in the poetry of the day, particularly in academy verse. For example, the subject of a poem in Repetida carrera (Valencia, 1659) is 'un galán que haciendo aire a su dama no pudo quitarle las moscas que se le pegaban al afeite' ${ }^{67}$ Polo de Medina also ridicules a lady for using an 'afeite' made from cat's intestines. ${ }^{68}$ The fact that Ramírez de Guzmán appears to have used such cosmetics herself, as the above décima suggests, may well account for the absence of a satirical treatment of this particular fashion in her poetry. ${ }^{69}$

The gifts took unusual forms on occasions. In a rare presence of domestic pets in seventeenth-century verse, Ramírez de Guzmán records with humour and ingenuity the

\footnotetext{
${ }^{66}$ Andrés Laguna, for example, called the fashion an 'infernal costumbre’: ‘Puédese hacer otro mayor disparate [...] que cubrir el rostro natural [...] con una hediondez de emplastos y cataplasmas?' See Mariló Vigil, La vida de las mujeres en los siglos XVI y XVII (Madrid: Siglo XXI, 1986), pp. 172-75. For criticism and defences of female cosmetics during the period, see Isabel Colón Calderón, 'De afeites, alcoholes y hollines', Dicenda. Cuadernos de Filología Hispánica 13 (1995), 65-82.

${ }^{67}$ See Jeremy Robbins, Love Poetry of the Literary Academies in the Reigns of Philip IV and Charles II (London: Tamesis, 1997), p. 79.

${ }^{68}$ See Adolfo de Castro (ed.), Poetas líricos de los siglos XVI y XVII, vol. 2. (Madrid: BAE, 1951), p. 201.

${ }^{69}$ Interestingly, another popular female fashion (ladies eating clay 'búcaros' to whiten their complexion) is satirised by the author in poem VI, entitled 'A una mujer tan amiga de barro que se desayunaba con él'.
} 
sending of a troublesome dog to a gentleman who agreed to give it a new home. In a neat closing play on words, she ventures that, for all the problems the dog can be expected to cause to its new owner, it may actually prove a blessing in disguise:

Llevan, señor, a Corcilla,

y según me ha dado guerra,

quisiera, más que a esta perra

en un labio una perrilla.

No os causará maravilla

que me alegre su destierro

si advertís en vuestro yerro;

pero si os agrada, basta

para poder hacer casta,

pues con la perra os dan perro. (LIII)

\section{Conclusion}

As the above examination of a representative selection of this large group of poems has attempted to show, the many poemas de circunstancias of Ramírez de Guzmán offer a curious blend of poetic representations of public and private occasions, ranging from official festivities and encomiastic celebrations of aristocrats to occurrences much closer to home. The parallels drawn here have helped establish that many of the pieces coincide broadly with the themes appearing in the occasional verse of contemporary authors, although the important focus on events and situations related to the poet's family and her immediate social environment in Llerena provides a highly interesting and revelatory contrast. Unlike much poetry of this type, where a specific occasion was often merely the pretext for stylised poetic representation, the occasions consigned to paper by Ramírez de Guzmán provide a connection with the real, everyday world. 
Viewed solely in terms of their at times trivial subject matters (but very much in keeping with poetic vogues) and their literary merit, several of the pieces could arguably be assigned the inferior value referred to by Hegel. However, as detailed reflections of everyday reality at multiple levels ${ }^{70}$ - at least the reality lived by a member of an affluent family in an Extremaduran provincial city - their sociohistorical value is undisputed.

Karl McLaughlin

Manchester Metropolitan University

All Saints Building

Manchester

M15 6BH

Email address: karl.mclaughlin@mmu.ac.uk

${ }^{70}$ The importance of the everyday to social life and for reconstructing the reality of past societies has been underlined by various social historians and sociologists. See, for example, Peter Berger and Thomas Luckmann, The Social Construction of Reality: A Treatise in the Sociology of Knowledge (Garden City NY: Anchor Books, 1987) and Michel de Certeau, The Practice of Everyday Life, translated by Steven Rendall (Berkeley: University of California Press, 1984). See also Alison Sinclair, "Have You Heard?' Negotiations of Transmission and Interpretation', MLR, 113 (2018), 502-17. 